\title{
SZEREPLŐ ÉS VISSZATEKINTŐ - EGY SZÖVEGTÍPUSRÓL JEGYZETKÉSZÍTÉS KÖZBEN
}

\section{ACTOR AND RETROSPECTIVE OBSERVER- ABOUT A TEXT-TYPE DURING NOTE MAKING}

\author{
Csorba László \\ az MTA doktora, egyetemi tanár, Eötvös Loránd Tudományegyetem Bölcsészettudományi Kar Történeti Intézet \\ csorba@hotmail.com
}

\section{ÖSSZEFOGLALÁS}

A szerző azt vizsgálja, hogy amikor Pavlovits Miklós interjújában Szabad György a saját életéről beszélt, akkor vajon kötött-e olvasóival „önéletrajzi paktumot", a szónak abban az értelmében, ahogy Philippe Lejeune használja híres könyvében. Amikor Szabad fölidézte emlékeit, vajon voltak-e kétségei azzal kapcsolatban, amire tanulmányaiban Pierre Bordieu utal, miszerint az önéletrajzban - minden jószándék ellenére - nemcsak rekonstrukciókat, hanem konstrukciókat is találhatunk?

\section{ABSTRACT}

The author examines if, when György Szabad is speaking about his own life in the interview made by Miklós Pavlovits whether he makes a 'biographical pact' with the readers in the sense of Philippe Lejeune's phrase in his famous book. Recalling his memories did Szabad have any doubts relating the idea which is expressed by Pierre Bordieu in his studies, that - in spite of all goodwill - we can find not only reconstructions, but constructions in them, too?

Kulcsszavak: életrajz, önéletrajz, Szabad György, önéletrajzi paktum, fikcionalitás

Keywords: biography, autobiography, György Szabad, autobiographical pact, fictionality

2013-ban jelent meg és elismerö figyelmet keltett az az interjúkötet, amelyet Osskó Judit építészmérnök, televíziós szerkesztő adott közre Antall József. Kései memoár. Publikálatlan interjúk címmel. A könyv azokat a beszélgetéseket tartalmazta, amelyeket a müsorkészítő 1992 júniusa és 1993 májusa között folytatott a miniszterelnökkel életpályájáról, a múlt és az akkori jelen politikaitársadalmi kérdéseiről. Az interjúsorozat nem könnyen született meg; úgy látszik, 


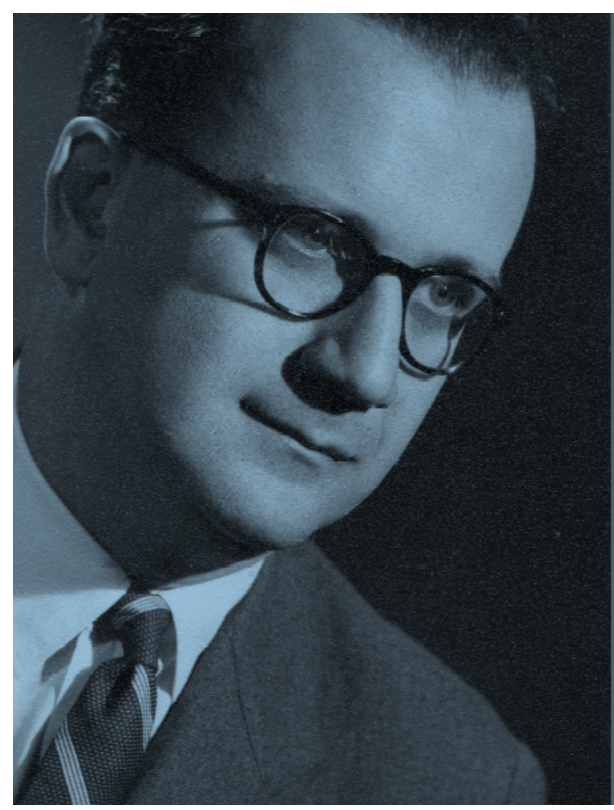

Szabad György, 1961 (a család tulajdona)

Antall jó ideig sajnálta az időt olyan eszmecserére, amelyről úgy vélte, túlságosan elvonja a napi munkától. A kötet utólagos alcíme - Kései memo$a ́ r$ - azonban jelzi, hogy a szerkesztő jó pszichológiai érzékkel rátalált arra a motívumra, amellyel fölkeltette az érdeklődést. „Arra gondoltam ugyanis - olvashatjuk az előszóban -, hogy a miniszterelnöknek tengernyi elfoglaltsága, a betegségével járó kezelések közepette nyilván nem jut ideje, energiája önéletrajzi visszaemlékezésre, naplóírásra. Az jutott hát eszembe: ha elfogad, elszegődöm mikrofonállványnak, meséljen a gyerekkoráról, a családjáról, a szellemi felkészüléséröl és mindarról, amit fontosnak, érdemesnek tart elmesélni az utókor számára." (Osskó, 2013, 12.)

Osskó Judit ötlete bevált: Antall vállalkozott rá, hogy - a „mikrofonállvány” inspiratív kérdéseit követve - mintegy fölvázolja imaginárius emlékiratainak alapvonalait, fölidézze az életrajzi fordulópontokat, elmesélje a legfontosabb történeteket, anekdotákat. Történészként és közéleti emberként fölismerte, hogy - versenyfutásban a halálos betegséggel - ez az utolsó lehetősége, hogy az általa megélt valóságról fölidézett emlékeit olyan értelmezésben mutassa be utódainak, ahogyan az - vállalva az örök szubjektivitást - szerinte helyes és érvényes.

Nos, amikor 2016 öszén fölkérést kaptam, hogy a Pavlovits Miklós által Szabad Györggyel készített interjúkötethez jegyzeteket írjak, mindjárt eszembe jutott Antallnak ez a gesztusa, és persze az is, hogy Pavlovits és Szabad beszélgetéssorozata épp akkoriban fejeződött be, amikor Osskó kérésére Antall kötélnek állt. Nem tartom elképzelhetetlennek, hogy - ismerve a miniszterelnök és a parlamenti elnök szoros munkakapcsolatát, továbbá közismerten baráti személyes viszonyukat - talán szóba került közöttük a „memoár helyett interjú” Szabad által frissen átélt szituációja. Azt gondolom ugyanis, hogy - leszámítva a betegség sürgetését Szabad motivációja valami hasonló lehetett, amikor 1991 őszén a szegedi újságíró jelentkezésére vállalta az életrajzi témájú beszélgetéseket. Túl 67. életévén, az ország túlzás nélkül egyik legelfoglaltabb embereként, amikor még voltak a memoárírásnál bizonnyal sürgősebbnek ítélt szakmai teendői ('́gy akadémiai rendes tagi székfoglalójának megírása, 1977-es Kossuth-kötetének újraformálása, anyai nagybátyjairól egy nagy család- és társadalomtörténeti monográfia elkészítése), nos, 
mindezek miatt nemigen bízhatott abban, hogy még valamikor eljöhet számára a személyes emlékiratokkal való bíbelődés békés időszaka. Ezért dönthetett úgy, hogy elfogadja a Pavlovits Miklós jelentkezésével megnyíló lehetőséget.

A feladatban rejlő kihívás annál erősebb lehetett, mivel Szabad természetesen jól ismerte a tudományos munkássága során általa legtöbbet kutatott és legnagyobbra tartott magyar államférfi, Kossuth Lajos 1870. december 30-án kelt sorait, melyekben azon sürgetésre válaszolt többeknek szóló, közös levélben, miszerint miért nem ír önéletrajzot. „Én [...] egy nemével a legyőzhetetlen undornak viseltetem az autobiographiák iránt - jelentette ki a Torinóban élő számüzött politikus -, mert lélektani okoknál fogva meg vagyok győződve, hogy a ki saját "viselt dolgainak" megörökítése végett veszen tollat kezébe, akarva, nem akarva azon ösztön befolyása alatt ír, hogy saját édes énje alakjának szögletességeit kidomborítsa, saját jellemének foltjait lecsiszolja, hibáit elsimítsa, vétkeit elfedezze vagy mások nyakába kerítse; általában hogy másokat minél kisebbeknek tüntessen fel, miszerint maga minél nagyobbnak látszassék."1 Aligha vitatható az államférfi lélektani megfigyelésének jogossága, amely ellen persze csak az lehet a viszonylagos ellenszer, ha az emlékiratíró bevallja örök szubjektív elfogultságát, és soha nem állítja azt, hogy az igazat, csakis az igazat írja - hanem csupán azt, hogy őszintén törekszik rá. A visszaemlékezésre vállalkozó Szabad György ugyanakkor nyilván abban is bízhatott, hogy talán a történész sok évtizedes forráskezelő rutinja valamiképp jelzi majd számára azokat a kényes pontokat, ahol különösen vigyáznia kell a személyes elfogultságnak a fölidézendő múltat eltorzítani képes veszélyeire.

Bár bizonyára számos megjegyzést lehetne tenni azzal kapcsolatban, hogy az élettörténeti interjú mennyiben tekinthetö önéletrajznak, ennél fontosabbnak ítélem annak jelzését, hogy Szabad mint visszatekintő nem érezte szükségét annak, hogy utaljon arra a meglehetősen összetett és sokoldalú problémacsoportra, amelyet a személyes emlékezés hitelességének lehetőségei, már-már szélsőségesen felfogott viszonylagossága témájában a 20. század végére a modern társadalomtudomány felhalmozott. A számos példa közül említsünk egy különösen provokatívat: az amerikai író, Raymond Federmann már 1981-ben közzétett, híressé vált Surfiction-kiáltványában így fogalmazott: „Az élet tehát fikció [...] és az életrajz valami olyasmi, ami utólag találja ki azt."2 Valóban, már a világhírü szociológus, Pierre Bourdieu is radikálisan megkérdőjelezte, hogy lehet-e egyáltalán valódi életrajzot írni. Állítása szerint az a vágy, hogy egy életutat valamiképp egy irányba mutató, koherens sorsként kezeljünk, akaratlanul is arra kényszeríti a

\footnotetext{
${ }^{1}$ Kossuth Lajos levele a Magyar Újság szerkesztőjének 1870. december 30-án. (Kossuth Lajos iratai, 1900, 330.)

2 „Life, also, is fiction... and a biography is something one invents afterwards” (idézi Szegedy-Maszák, 1986).
} 
biográfust, hogy feldarabolja az életpályát ,értelmes viszonyok mentén elrendezett képsorokra", és mintegy följogosítja arra, hogy eldöntse, mik egy valós életpálya jelentősnek ítélt mozzanatai - azok ugyebár, amelyek a kiválasztott „koherens sorsba" illeszkednek -, és mik azok, amelyeket mint mellékeseket figyelmen kívül lehet, sőt kell hagyni. Ám Bourdieu szerint ez az elképzelés színtiszta „retorikai illúzió", mert az életpálya valójában diszkontinuus események, tettek, érzetek egymásutániságából tevődik össze, voltaképpen mindenféle értelmet nélkülöző káosz, amelynek eseményei csupán az egyén tudatában vagy az azokat érzékelő szemtanúk szemléletében nyerhetnek - szükségszerüen fiktív - egységet. Az életpálya látszólagos egysége tehát valójában csupán az életút ideológiájának a reprezentációja: ez visz rendet abba a kibogozhatatlan rendetlenségbe, amilyen tulajdonképpen az egész élet. ${ }^{3}$

Aki az Aradtól az Országgyülésig kötetbe belelapoz, azonnal észreveszi, hogy Szabadtól távol állt ez a felfogás: amikor ugyanis ifjúságát és történészitanári pályáját fölidézte, ugyanazon a nyelven beszélt, mint amelyen „tematikus” monográfiáit, szintéziseit, szaktanulmányait megírta. Ezt a nyelvi alaphelyzetet pedig értelmezhetjük úgy, mintha annak használója kimondatlanul is elvárná: a szubjektív érintettség és a nélkülözhetetlen történeti távlat hiánya ellenére is kijelentéseit ugyanolyan érvényesnek tekintse az olvasó, mint amikor kedvenc 19. századi forrásait elemzi. Ha az önéletírás pszichológiájának nemzetközi hírü kutatója, Philippe Lejeune francia irodalomtörténész közismert kategorizálását használjuk, akkor azt mondhatjuk, hogy Szabad e kötetében nem tudatosan, de ún. önéletírói paktumra tett ajánlatot olvasójának: eddigi tudományos hírnevét, életművét, sőt politikusi teljesítményét mint összegeződő pszichológiai és társadalmi „tőke-óvadékot” kínálta fel garanciaként arra, hogy szubjektív közléseit is hitelesnek fogadjuk el. Az így kialakuló valamiféle ,igazság-egyezség” szerzői oldalán a visszaemlékezö-történetmondó legjobb igyekezete szerint törekszik arra, hogy elbeszélése minél közelebb legyen az általa átélt egykori valóságról megörzött emlékeihez (akár vannak, akár nincsenek kételyei neki vagy nekünk az ügyben, hogy ez egyáltalán mennyire lehetséges, mennyire sikerülhet), míg a befogadói oldalon az olvasó mintegy kötelezettséget vállal arra, hogy nem vitatja az elbeszéltek igazságértékét (Lejeune, 2002). Persze a paktumot nem kötelező megkötni, így Lejeune-t számos kritika érte amiatt, hogy - az irodalmi alkotások ma már klasszikusnak számító befogadói megközelítését követve - az olvasót ez ügyben mintegy a bíró szerepkörébe helyezte. Ám mégis, az aligha vitatható, hogy ez az olvasói mérlegelő hozzáállás bizonyos mértékig valóban létezik, így meggyőződésem, hogy Szabad kötetének esetében is az olvasók többsége elsősorban éppen attól függően fogadja majd el hitelesnek, vagy éppen utasítja el a tudós és politikus szerző önmagáról megfogalmazott kijelentéseit, vagyis olvassa

\footnotetext{
${ }^{3}$ Pierre Bourdieu gondolatait és az egész kérdéskört részletesen tárgyalja Gueniffey, 2000.
} 
az elmúlt évtizedekről szóló igaz vagy netán torzító beszámolóként a kötetet, hogy miképpen viszonyul az említett paktum garanciális elemeihez - tehát mindahhoz, amit e könyvön kívül tud, hisz, képzel, gondol a szerző-visszatekintő személyéről és teljesítményéröl.

A gondolatmenetet lezárva még azt jegyezhetjük meg, hogy mindezek a megfontolások szorosabban véve csak a kötet első hat fejezetére (valamivel több mint a szöveg felére) vonatkoznak, mivel a VII. fejezettől a nyelv és részben a stílus is megváltozik: a kérdések ettől kezdve már nem a múltra, hanem a házelnök akkori napi politikai és törvényhozási tevékenységére vonatkoznak. Ez az eszmecsere persze a mából visszatekintve az 1990-es évek elejére vonatkozóan igen értékes forrásanyagnak tekinthető, ráadásul szintén nagyon érdekes olvasmány - ám egyszerüen müfajilag más szöveg, mint a korábbi, mert Szabad beszédhelyzete megváltozott: ettől kezdve már nem a visszaemlékező, hanem a kortárs szereplő véleményét és gondolatait rögzítette a magnetofon.

Mivel jegyzetkészítés közben nemcsak elvi, hanem gyakorlati problémákról is morfondíroz az ember, úgy vélem, érdemes néhány szót szólni a szöveg technikai értelemben vett hitelességéről is. Minden tiszteletet és elismerést megérdemel a sajtó alá rendezők, maga Pavlovits Miklós, továbbá Szabadné Suján Andrea és Szabad Júlia jóformán restaurátori-filológusi munkája, amellyel a szöveget rekonstruálták, a hangszalagokat újrahallgatva a korábbi gépirat elütéseit, tévedéseit stb. javították. Ám minderre azért volt szükség, mert ez a szöveg tizennégy évig a szekrényben lapult, és a szerző-szereplö-visszaemlékezőnek most, a közzétételkor már nem állt módjában újra elolvasni, és a maga elképzelései szerint véglegessé formálni az élettörténeti interjút.

Márpedig e helyzetből adódhatnak bizonyos problémák. Analógiaként megemlíthetjük Szegedy-Maszák Mihály figyelmeztetését, aki A megértés módozatai címü kötetében így utalt egy, a Kosztolányi Dezső levelezésének kiadásával foglalkozó írására: „Ebben a tanulmányban nemcsak azt igyekeztem érzékeltetni, hogy megbízható kiadás csakis olyan szövegeket tartalmazhat, amelyeket a sajtó alá rendező saját szemével látott és hitelesnek talált, de azt is, mennyire veszélyes lehet töredékesen fönnmaradt levelezés alapján megrajzolni egy személyiséget." (Szegedy-Maszák, 2003, 50.)

E figyelmeztetést megszívlelve, érdemes nyomatékosan utalni arra, hogy Szabad nagy ,átíró” volt, vagyis a szövegein szinte mindig, az utolsó pillanatig változtatott. Amikor az újságíró kérdéseit követve belemerült ifjúságának, felnőtt életének, megpróbáltatásainak, kudarcainak és győzelmeinek részleteibe, bizonyosan azzal a tudattal, azzal a felszabadultsággal tette ezt, hogy utólag nem csupán az átírás klasszikus elhallásait fogja majd kiigazítani, de ha netán bármilyen tartalmi vagy hangulati elemmel is problémája lenne, mert az emlékezés hevében esetleg elragadták volna az érzelmei vagy az indulatai stb., akkor azt is módjában lesz kijavítani. Miközben tehát a sajtó alá rendezők természetesen nem tehettek 
mást, mint szorosan követték a szalagokon fönnmaradó szöveget, a magam részéröl biztos vagyok benne, hogy utólag, javító tollal a kezében, Szabad György alighanem jó néhány megfogalmazáson, kifejezésen és szóalakon, stiláris fordulaton változtatott volna, ha ezt az esélyt a sors megadja neki. Ám rajta is múlott, hogy erre nem került sor, hiszen az átiratot ő tette el szekrényébe, és nem is vette elő soha többé. Hogy miért nem, annak egyik motívumára már utaltam korábban: a házelnökség idején maga elé tüzött, az önéletírásnál sürgősebbnek ítélt három tudományos feladatából kettőt (a rendes tagi székfoglaló és a Kossuth irányadása kötet elkészítése) sikerült megvalósítania, de a harmadikra már nem maradt ideje: nagybátyjainak története örökre cédulákban maradt az íróasztalán. Ám épp ezért azokra a tennivalókra sem keríthetett már sort, amelyeket esetleg ezt követően vett volna fel a munkalistára.

Mindez persze nem jelenti azt, hogy a szöveget nem kellett volna kiadni, hiszen a benne olvasható számos fontos és érdekes információ messze-messze fölülmúlja a problematikus elemeket. Az olvasó azonban számolhat azzal - amiként másfelől a közreadók is joggal bízhatnak benne -, hogy ha a kötetet lapozgató egy-egy fordulatnál netán úgy vélheti, nem az ,igazi” Szabadot hallja, akkor arra is gondolhat, hogy a szerző talán éppen azt az adott fogalmazást is átjavította volna, ha módja van rá.

Búcsúzóul kanyarodjunk vissza az önéletrajz fikcionalitásának föntebb már emlegetett kérdésköréhez. Szabad otthonában három Nagy István-pasztellkép függ a falon: tanyákat ábrázolnak a müvészre oly jellemző, realista-konstruktivista stílusban. Az erdélyi származású festőművész képeit különösen kedvelte, és ha a téma fölmerült, nem csupán a mủvek esztétikai értékeiről beszélt avatott lelkesedéssel, hanem társadalomtörténeti súllyal emlegette, miszerint a székely őstehetség érvényesülésében komoly szerepet játszott a zsidó származású pesti vállakozó-nagypolgár, a neves könyvkiadó Wolfner József figyelme és anyagi segítsége (ilyenkor persze az is szóba került, hogy Wolfner a két világháború közötti magyar festészet egyik óriásának, Farkas Istvánnak volt az édesapja). Miközben úgy vélem, ez az apró mozzanat roppant jellemző az egész személyiségre, tehát olyan tükörcserép, amelyben egész világ villan fel különös élességgel, vagyis egy Szabad György-portré nem lenne teljes nélküle - eközben ő maga az előttünk fekvő kötetben képzőmüvészeti vagy zenei ízlését még csak meg sem említette ifjúsága érdemi formálójaként. Ez a motívum is tehát olyasmi, ami mintha erösítené az autobiográfiakkal kapcsolatos posztmodern szkepszist. Aki a saját sorsára visszatekint, valójában konstruktőr, és választásaival talán ugyanannyit, vagy még többet takar el, mint amennyit megmutatni szeretne - és így könnyen lehet, hogy csak hiszi azt, hogy önmagáról a valóságot mondja el. Ehelyett faragott képet készít, sorsának valamiféle ideologikus reprezentációját, ami persze - kellő tehetség és tudás esetén - akár igazi mủalkotás is lehet, és vagy tudományos szakszerűséggel tudósít a szereplő életének mindennapi tárgyi 
valóságáról, vagy éppen fordítva: olyan elvontan beszél róla, mint egy absztrakt müalkotás. Ám ha az egész személyiségre vagyunk kíváncsiak, akkor ez nem feltétlenül baj, mert bármennyire is konstruált ez a kép, általa új valóság keletkezik, amely részévé válik az eredeti életnek, és így a történész számára akaratlanul is újabb forrásanyagot és újabb szempontokat ad annak értelmezéséhez. Segít tehát minket az életrajzok és önéletrajzok azon örök kérdésének megválaszolási kísérleteiben, amelyet talán Paul Ricoeur fogalmazott meg a legtalálóbban: mindig azt keressük, miképpen lehet valaki önmaga, ha már nem ugyanaz, aki egykor volt.

\section{IRODALOM}

Gueniffey, P. (2000): A biográfia a megújuló politikatörténetben. Aetas, 3, 148-149. http://acta. bibl.u-szeged.hu/40959/1/aetas_2000_003_136-149.pdf

Kossuth F. (S. a. r.) (1900): Kossuth Lajos iratai. VIII. Budapest: Athenaeum

Lejeune, P. (2002): Az önéletírás meghatározása. (ford. Z. Varga Z.) Helikon, 3, 272-285.

Osskó J. (2013): Antall József. Kései memoár. Publikálatlan interjúk. Budapest: Corvina Kiadó

Szegedy-Maszák M. (1986): The Life and Times of the Autobiographical Novel. Neohelicon, XIII/1, 83-104. DOI: 10.1007/BF02118115

Szegedy-Maszák M. (2003): A megértés módozatai: forditás és hatástörténet. Budapest: Akadémiai Kiadó 